\title{
Reproductive Biology of Female Prairie \\ Rattlesnakes (Crotalus viridis viridis) in Alberta.
}

Fish \& Wildlife Division

RESOURCE DATA AND

SPECIES AT RISK SECTION

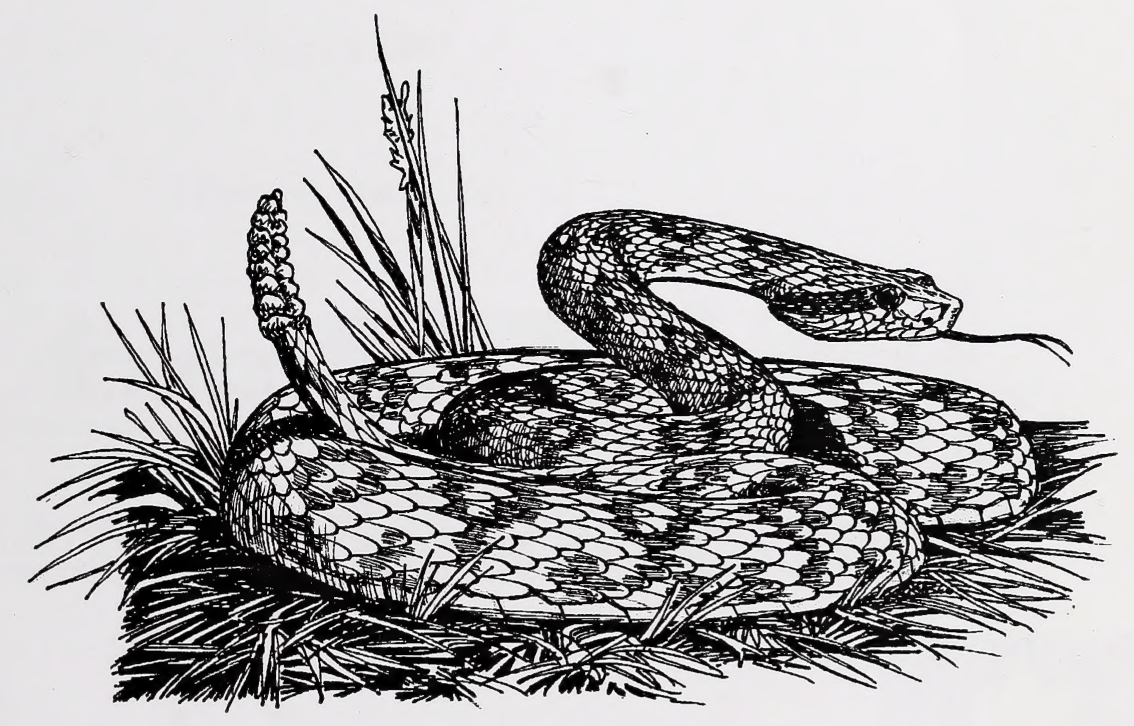

Alberta Species at Risk Report No. 103 
Digitized by the Internet Archive in 2016 
Reproductive Biology of Female Prairie Rattlesnakes (Crotalus viridis viridis) in Alberta.

\author{
Dennis Jørgensen \\ Joel Nicholson
}

Alberta Species at Risk Report No. 103

March 2007

Project Partners:

Alberla

SUSTAINABLE RESOURCE DEVELOPMENT

Fish \& Wildlife
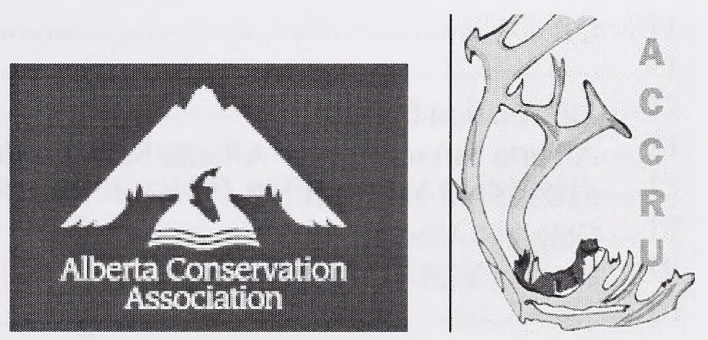

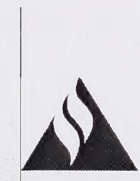

A ALBERTA SPORT, RECREATION

calgaryzoo PARKS \& WILDLIFE FOUNDATION

Enhancing Alberta's Communities

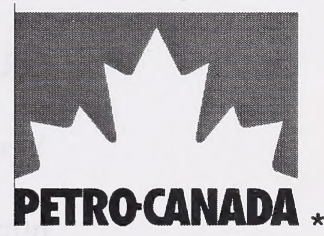

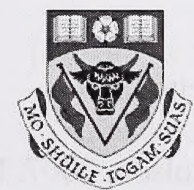

UNIVERSITY OF

CALGARY

FACULTY OF ENVIRONMENTAL DESIGN 
Publication No. I/263

ISBN: 978-0-7785-5425-7 (Printed Edition)

ISBN: 978-0-7785-5426-4 (On-line Edition)

ISSN: 1463-7219 (Printed Edition)

ISSN: 1496-7146 (On-line Edition)

Cover Illustration: Brian Huffman

For copies of this report contact:

Information Centre-Publications

Alberta Environment / Alberta Sustainable Resource Development Main Floor, Great West Life Building 9920108 Street

Edmonton, Alberta,

Canada T2K 2M4

Telephone: (780) 422-2079

OR

Information Service

Alberta Environment / Alberta Sustainable Resource Development \#100, 311512 Street NE

Calgary, Alberta

Canada T2E 7J2

Telephone: (403) 297-3362

OR

Visit our website at:

http://www.srd.gov.ab.ca/fw/speciesatrisk/reports.html

This publication may be cited as:

Jørgensen, D. and J. Nicholson. 2007. Reproductive Biology of Female Prairie Rattlesnakes (Crotalus viridis viridis) in Alberta. Alberta Sustainable Resource Development, Fish and Wildlife Division, Alberta Species at Risk Report No. 103, Edmonton, AB. 


\section{TABLE OF CONTENTS}

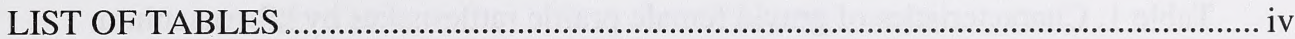

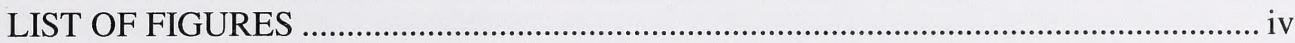

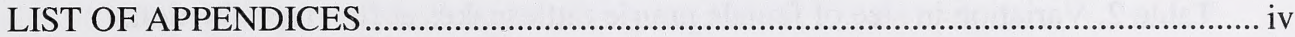

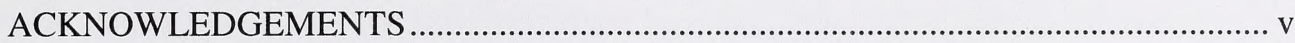

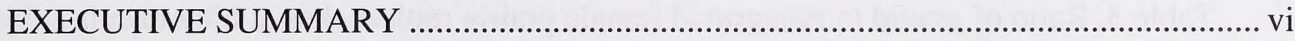

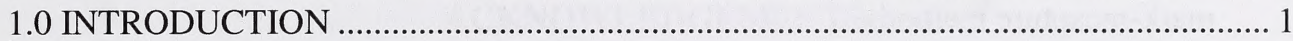

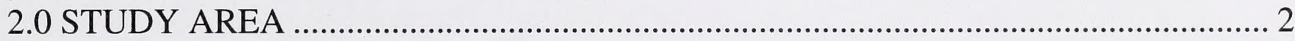

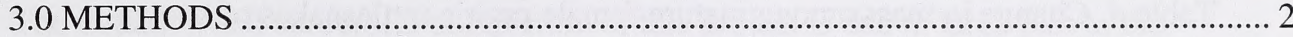

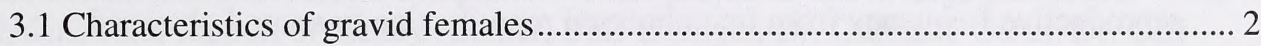

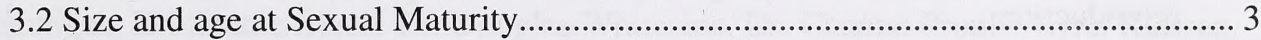

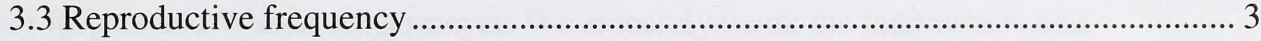

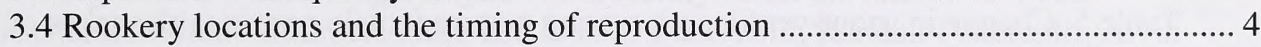

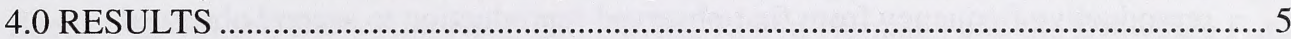

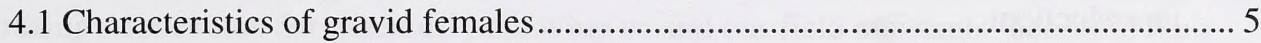

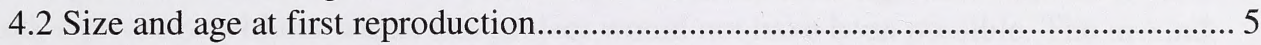

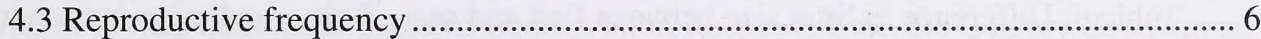

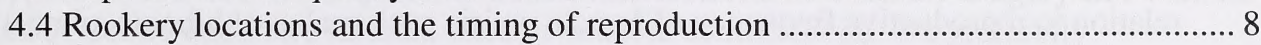

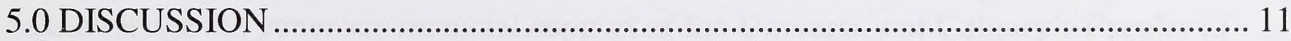

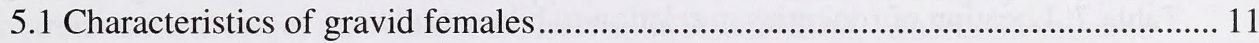

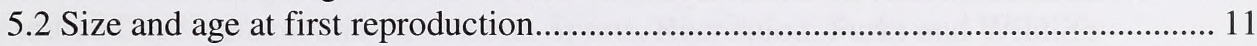

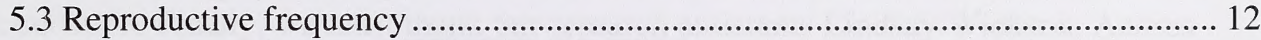

5.4 Rookery locations and the timing of reproduction ................................................ 14

6.0 RECOMMENDATIONS FOR FUTURE RESEARCH AND MANAGEMENT ..... 15

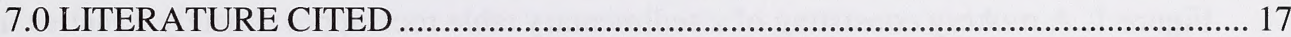

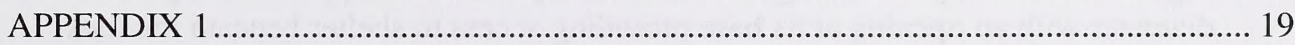

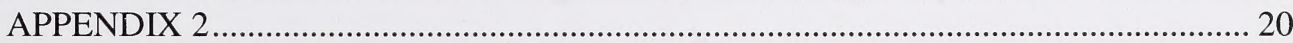




\section{LIST OF TABLES}

Table 1. Characteristics of gravid female prairie rattlesnakes by hibernaculum.

Table 2. Variation in size of female prairie rattlesnakes at first reproduction.

Table 3. Ratio of gravid to non gravid female prairie rattlesnakes at hibernacula subject to mark-recapture methods.

Table 4. Change in mass among mature female prairie rattlesnakes of known reproductive frequency from first observed reproduction to second observed reproduction.

Table 5. Change in snout-vent length among mature female prairie rattlesnakes of known reproductive frequency from first observed reproduction to second observed reproduction.

Table 6. Difference in litter size between first and second observed reproduction in relation to reproductive frequency of female prairie rattlesnakes at hibernaculum 1.

Table 7. Location of rookeries in relation to hibernacula.

\section{LIST OF FIGURES}

Figure 1. A rookery consisting of a sedimentary table rock approximately 2 metres in diameter with an opening at its base providing access to shelter beneath the rock.

Figure 2. A rookery consisting of an abandoned mammal burrow dug in a sandy substrate. The mouth of this hibernaculum is approximately $20 \mathrm{~cm}$ in diameter.

\section{LIST OF APPENDICES}

Appendix 1. Capture history and reproductive status of mature females from spring 2004 to fall 2006 at hibernaculum 1

Appendix 2. Capture history and reproductive status of mature females from spring 2004 to fall 2006 at hibernaculum 2 


\section{ACKNOWLEDGEMENTS}

The initiation and successful completion of this project is due in large part to the guidance and support of Kelley Kissner, Dale Eslinger, Dr. Cormack Gates, Dr. Carl Hannigan, Dr. Sandie Black, Dr. Douglas Whiteside, Dr. Chantal Proulx, Lynn Klassen, Lori Rogers and Wanda Angermeyer. We sincerely thank the landowners and leaseholders Annie Bullman, Aldo and Glenda Pederzolli, Randall Pederzolli, Alvin Baedke, Erwin and Betty Ann Neal, Bill Davies, Robyn Hermann and the Drowning Ford Grazing Association for graciously allowing us and our field assistants' access to their land, a privilege without which this project would not have been possible. The in-kind support of the Alberta Cooperative Conservation Research Unit, the Calgary Zoo Animal Health Centre and Petro Canada were invaluable contributions. We gratefully acknowledge the generous financial support of the University of Calgary's Faculty of Environmental Design, the Alberta Conservation Association, Alberta Sustainable Resource Development and the Alberta Sports, Recreation, Parks and Wildlife Foundation. Finally, we must thank our research assistants Lindsay Wickson, Andres Eduardo Estay Stange, and Rob Williams for their friendship and dedication. 


\section{EXECUTIVE SUMMARY}

Many aspects of the biology of prairie rattlesnakes, Crotalus v. viridis, in Alberta are not well described. We used mark-recapture to follow the reproductive histories of female prairie rattlesnakes, Crotalus viridis viridis, at two hibernacula in southeastern Alberta over a three year period (2004-2006). In addition, we used radio-telemetry to track the movements of females, revealing the location of several rookeries where gravid females were aggregated. This study permitted assessment of several parameters including mean mass and snout-vent length of gravid females, size at sexual maturity, the number of gravid to non-gravid mature females at hibernacula, mean litter size, mean mass lost at parturition (birth), growth between reproductive intervals, reproductive frequency, and timing of reproduction, and provided information on the location of rookeries in relation to hibernacula. This knowledge contributes to our understanding of the species capacity to recover should populations decline, and a measure of the resilience of the species and its habitat to direct or indirect environmental pressures, aiding wildlife managers to determine the appropriate conservation status.

Mean litter size at our study sites varied from approximately 8 to 9.5 ova or embryos per mature female (range of 4-13) among four hibernacula. Litters are therefore intermediate in size relative to other northern prairie rattlesnake populations. The smallest sexually mature female identified measured $68.5 \mathrm{~cm}$ long. Age at sexual maturity among females was liberally estimated to be between four and eight years of age, encompassing the range of estimates for other northern prairie and western rattlesnake populations. The ratio of gravid to non-gravid females sampled in our study fluctuated widely between years at both hibernacula. The reproductive histories of 57 mature adult females were followed over three years but we only determined the reproductive frequency of six mature females at one hibernaculum. Three females exhibited a two year reproductive cycle and three exhibited a three year reproductive cycle.

Twelve rookeries were located during the study and all occurred within 500 meters of known hibernacula. In addition, several rookeries were associated with each hibernaculum. These observations are similar to other studies of the Alberta population of rattlesnakes and to other populations in the northern portion of the species' range. The composition, location and aspect of rookeries appeared to be largely dependent on local conditions and opportunities available in the vicinity of hibernacula. Some gravid females were observed to occupy more than one rookery during gestation. Twenty-one gravid females began dispersing from hibernacula from late April to early June. Gravid females were first detected at rookeries in early May and parturition occurred between midAugust to mid-September. The greatest number of neonates counted at a single den site ranged from six to 18 . Some gravid females were observed to occupy more than one rookery during gestation. Movement during gestation may provide additional foraging opportunities or may be the result of perceived threats at one rookery (e.g. predators), resulting in relocation to another rookery. 
Recommendations for future research and management of rattlesnakes in Alberta include increasing setback distances for human activities around hibernacula to 500 metres, advising caution in the use of implanted radio-transmitters to track gravid females, and identifying hibernacula where the persistence of a population is a concern. At hibernacula where the persistence of populations are a concern managers should consider the value of enhancing habitat for rattlesnake prey and providing additional cover for gravid females in the vicinity of hibernacula. We recommend additional research to quantify direct mortality sustained as a function of human activities, particularly agriculture, the effects of which are less easily measured than road mortality. Continued study of marked females would provide more detailed information regarding variation in reproductive characteristics of female rattlesnakes in Alberta. 


\subsection{INTRODUCTION}

Reproduction is a critical component of the life history of all wildlife species. Knowledge of the reproductive biology of a species can, among other things, provide an indication of the species capacity to recover should populations decline, and a measure of the resilience of the species and its habitat to direct or indirect environmental pressures, aiding wildlife managers to determine the appropriate conservation status. In Alberta, the prairie rattlesnake is designated as "May Be at Risk" of extinction under The General Status of Alberta Wild Species 2005 (Alberta Sustainable Resource Development 2006). However, relatively few scientific investigations of prairie rattlesnakes, Crotalus $v$. viridis, have been conducted in Alberta (Powell et al. 1997, Didiuk 1999) and many aspects of the biology of the Alberta population are not well described. The species has been the subject of several short-term scientific investigations in Saskatchewan (Gannon 1980; Gannon and Secoy 1984; Gannon and Secoy 1985, MacKay 1987; Macartney and Weichel 1989, Macartney and Weichel 1993, Kissner et al. 1996) and long-term scientific investigations in Wyoming (Duvall et al. 1985, Duvall et al. 1990, King and Duvall 1990, Graves and Duvall 1993). Consequently, much of our detailed knowledge of the species' biology is derived from other regions.

Extrapolation from studies of prairie rattlesnakes occupying similar environments may be appropriate and necessary, but prairie rattlesnakes are broadly distributed (north-central Mexico to southeastern Alberta and southwestern Saskatchewan), and reproductive traits and behaviours may vary in response to environmental conditions that differ across the species' range. In Alberta, the prairie rattlesnake is currently legally designated as "data deficient", although anecdotal evidence suggests that their numbers have declined. Both the current legal designation and the apparent decline of prairie rattlesnakes in Alberta suggest a need for local studies to assess aspects of the species biology that will contribute to our understanding of population trends, facilitating the future recommendation of an appropriate legal designation by the Alberta Endangered Species Conservation Committee.

Our research on the behaviour and ecology of prairie rattlesnakes near Medicine Hat, Alberta provided an opportunity to gather information on a number of aspects of female prairie rattlesnake reproductive biology. We used mark-recapture to follow the reproductive histories of females at two hibernacula over a three year period (20042006), to gain knowledge regarding reproductive traits and behaviours of female prairie rattlesnakes in this region. In addition, we used radio-telemetry to track the movements of female prairie rattlesnakes. Although the majority of radio-tagged rattlesnakes were nongravid females, we found that initial movements of these females away from hibernacula often revealed the locations of rookeries where gravid females were aggregated, facilitating observations of gestation and parturition (birth). This study permitted assessment of several parameters including mean mass and snout-vent length of gravid females, size at sexual maturity, the number of gravid to non-gravid mature females at hibernacula, mean litter size, mean mass lost at parturition, growth between reproductive intervals, reproductive frequency, and timing of reproduction, and provided information 
on the location of rookeries in relation to hibernacula. Knowledge of these traits and their variability is important in future assessments of the effects of direct and indirect environmental pressures on prairie rattlesnake populations in southeastern Alberta, in determining their resilience to these pressures, and in developing appropriate management strategies for their conservation.

\subsection{STUDY AREA}

The reproductive status of mature female prairie rattlesnakes was monitored and assessed over a three year period (2004-2006) at hibernacula within the South Saskatchewan River Valley lowlands near Medicine Hat, Alberta $\left(50^{\circ} 1^{\prime} \mathrm{N} ; 110^{\circ} 43^{\prime} \mathrm{W}\right)$. Two hibernacula were sampled within one study area approximately $20 \mathrm{~km}$ north of Medicine Hat. This study area was primarily provincial land under grazing disposition consisting of native mixed-grass prairie, with limited amounts of privately owned land subject to cultivation. Significant oil and gas development has also occurred in this area. Two hibernacula were sampled in a second study area approximately $13 \mathrm{~km}$ west of Medicine Hat. The land in the river valley surrounding these sites was privately owned and leased land consisting of native mixed-grass prairie subject to cattle grazing, while the associated upland consisted almost entirely of privately owned cultivated land (both dry land and irrigation) with some tame pasture and rural residential development. The two study areas were approximately $26 \mathrm{~km}$ apart.

\subsection{METHODS}

\subsection{Characteristics of gravid females}

During the active seasons (April to October) of 2004 and 2005 drift fences were erected at two hibernacula (hereafter referred to as hibernacula 1 and 2), one within each of the two study areas. Funnel traps were installed and checked on a daily basis to capture snakes leaving the hibernaculum in the spring and returning to the hibernaculum in the fall, but traps were removed between these times to allow free movement of snakes for the remainder of the active season. In the spring of 2006, captures were made opportunistically at hibernaculum 1 , and hibernaculum 2 was not visited. In the fall of 2006 funnel traps were again installed at hibernacula 1 and 2 to allow recapture of as many marked rattlesnakes as possible. Two hibernacula (hereafter referred to as hibernacula 3 and 4), one within each of the two study areas, were not fenced. Instead, these sites were visited several times in the fall of 2005 (between 8 to 29 August) and rattlesnakes were captured opportunistically at hibernaculum openings. Rattlesnakes captured at each of the four hibernacula were scanned for passive integrated transponder (PIT) tags (AVID) that might previously have been implanted, measured, sexed, palpated to identify and count food boli and/or developing ova or embryos, marked with a PIT tag if not previously captured, weighed and released. Neonates and juvenile rattlesnakes with snout-vent lengths of less than $45 \mathrm{~cm}$ were not marked. The number of developing 
embryos or ova detected during ventral palpation was used as an index approximating litter size because it was rarely possible to assess clutch size at parturition for freeranging females.

\section{$\underline{3.2 \text { Size and age at Sexual Maturity }}$}

As in other studies of reproduction in rattlesnakes, we estimated the size at sexual maturity for females as the shortest snout-to-vent length (SVL) of a female captured with enlarged ova or with embryos. Variation in size at sexual maturity was estimated for females whose reproductive history was followed from the time they were juveniles (shorter than our threshold SVL value) to the time when enlarged ova or embryos were first detected. It is extremely difficult to reliably estimate the age of a rattlesnake that has not been marked since birth because growth of rattlesnakes is variable depending on resource acquisition and conversion efficiency, and can potentially be influenced by environmental factors (e.g., temperature). When a rattlesnake's rattle is complete it indicates how many times a rattlesnake has shed since birth and provides an estimate of age if shedding frequency is known (Gannon 1980, Macartney and Weichel 1989); however, observations of shedding frequency have demonstrated that in some cases a rattlesnake will not shed in a year of limited growth or it may shed as many as three times in a year of extreme growth (D. Jørgensen, unpubl. data; Diller and Wallace 2002). Years of extreme growth are commonly observed among young rattlesnakes and more often result in 2 sheds/year. Therefore estimates of age at sexual maturity based on calculations using a fixed number of sheds per year should be considered rough estimates. Based on this information, age at sexual maturity was estimated using 1 shed per year as an upper limit and 2 sheds per year as a lower limit.

\section{$\underline{3.3 \text { Reproductive frequency }}$}

In short-term studies or studies that do not follow marked individuals, reproductive frequency of females is commonly based on the ratio of the number of gravid to nongravid mature females in a population (Macartney and Weichel 1993). For example, if half of the mature females captured at a hibernaculum in spring are gravid it is estimated that the reproductive cycle is biennial, or if a third of the mature females captured are gravid then the reproductive cycle is estimated to be triennial.

In this study, the ratio of gravid to non-gravid mature females at a hibernaculum was estimated based on information gathered during both spring and fall captures. When females with developing ova were detected returning to the hibernaculum in the fall they were assumed to be among the gravid females at the hibernaculum the following spring regardless of whether they were recaptured, and were therefore counted as gravid females in the annual ratio calculation. Similarly, non-gravid females detected in the fall were assumed to be among the non-gravid females at the hibernaculum the following spring regardless of whether they were recaptured and were therefore counted as non-gravid females in the annual ratio calculation. Of the 57 mature females captured a combined 
total of 146 times during our mark-recapture study at hibernacula 1 and 2 (Appendix 1 and 2), our assessment of reproductive status only proved incorrect in one instance when a female that was judged to be non-gravid in the fall was found to be post-partum (i.e., had given birth) the following fall.

The reproductive status of females was determined by ventral palpation at the time of each capture. Females were classified as either non-gravid, carrying developing ova or gravid. Assessing reproductive status allowed us to construct a reproductive history of individual females over the duration of the study, potentially permitting assessment of the reproductive frequency of individual females. We defined the reproductive frequency of an individual as the time in years between detecting enlarged ova in one season and enlarged ova in another season, or detecting embryos in one season and embryos in another season.

\subsection{Rookery locations and the timing of reproduction}

While radio-tracking non-gravid females during their initial dispersion from hibernacula, some shelter sites they selected were found to be occupied by other rattlesnakes. These other rattlesnakes were captured using snake tongs and were scanned for a PIT tag, if none was found they were measured, sexed, palpated to identify and count food boli, developing ova or embryos, marked with a PIT tag, weighed and released. These locations were then recorded and named using a handheld GPS unit (Garmin $12 \mathrm{XL}$ ) and the PIT tag numbers of individuals occupying these sites were recorded. These sites were subsequently revisited to monitor whether they continued to be occupied by rattlesnakes throughout the active season, whether they were occupied by the same individuals, and whether these individuals were gravid females. Repeated observations of the presence of gravid females at a site during the gestation period were considered one indication of the occurrence of a rookery. A second indication of the occurrence of a rookery involved confirmation of parturition at a site. 


\subsection{RESULTS}

\subsection{Characteristics of gravid females}

We captured between eight and 23 gravid females at each hibernaculum between 2004 and 2006 (Table 1). Mean SVL across sites varied from $79.7 \pm 7.3 \mathrm{~cm}$ to $87.1 \pm 9.1 \mathrm{~cm}$, while the shortest gravid female measured $68.5 \mathrm{~cm}$ and the longest measured $106.7 \mathrm{~cm}$. Mean mass across sites varied from $384.8 \pm 107.7$ grams to $421.8 \pm 134.9$ grams, with the smallest gravid female weighing 260 grams and the largest weighing 698 grams. Mean litter size across sites varied from $7.9 \pm 2.6$ to $9.5 \pm 1.5$, ranging between 4 and 13 ova or embryos. The percent mass lost at parturition was measured at hibernacula 1 and 2 because these are the only sites where females were marked and recaptured. The mean percent mass lost at parturition varied from $32.1 \pm 8.1 \%$ to $38.0 \pm 6.5 \%$, ranging between $22.6 \%$ and $45.4 \%$.

Table 1. Characteristics of gravid female prairie rattlesnakes by hibernaculum.

\begin{tabular}{|c|c|c|c|c|c|}
\hline Hibernaculum & $\begin{array}{c}\text { Gravid } \\
\text { females } \\
\text { (N) }\end{array}$ & $\begin{array}{c}\text { Mean SVL } \\
\text { cm } \pm \text { SD } \\
\text { (range) }\end{array}$ & $\begin{array}{c}\text { Mean mass } \\
\mathrm{g} \pm \mathrm{SD} \\
(\text { range) }\end{array}$ & $\begin{array}{c}\text { Mean } \\
\text { litter } \\
\text { size } \\
\pm \text { SD } \\
\text { (range) }\end{array}$ & $\begin{array}{c}\text { Parturition } \\
\% \text { mass lost } \\
\pm \text { SD } \\
\text { (range) }\end{array}$ \\
\hline 1 & 23 & $\begin{array}{c}82.7 \pm 8.6 \\
(68.6-106.7)\end{array}$ & $\begin{array}{c}421.8 \pm 134.9 \\
(260-698)\end{array}$ & $\begin{array}{c}8.0 \pm 1.8 \\
(6-12)\end{array}$ & $\begin{array}{c}38.0 \pm 6.5 \\
N=10 \\
(23.6-45.4)\end{array}$ \\
\hline 2 & 15 & $\begin{array}{c}79.7 \pm 7.3 \\
(68.5-104.8)\end{array}$ & $\begin{array}{c}384.8 \pm 107.7 \\
(275-685)\end{array}$ & $\begin{array}{c}7.9 \pm 2.6 \\
(4-13)\end{array}$ & $\begin{array}{c}32.1 \pm 8.1 \\
N=6 \\
(22.6-45.0)\end{array}$ \\
\hline 3 & 8 & $\begin{array}{c}87.1 \pm 9.1 \\
(74.6-100.2)\end{array}$ & $\begin{array}{l}418.6 \pm 129.9 \\
(277.5-635.5)\end{array}$ & $\begin{array}{c}9.5 \pm 1.5 \\
(7-11)\end{array}$ & NA \\
\hline 4 & 11 & $\begin{array}{c}85.03 \pm 4.33 \\
(77.5-94.8)\end{array}$ & $\begin{array}{c}407.5 \pm 90.5 \\
(292.5-630.5)\end{array}$ & $\begin{array}{c}8.7 \pm 1.7 \\
(6-12)\end{array}$ & NA \\
\hline
\end{tabular}

NA - not applicable, females were not recaptured precluding measurement of mass loss.

\subsection{Size and age at first reproduction}

The smallest gravid females identified at each of the fenced hibernacula were similar in size. At hibernaculum 1 the smallest gravid female was $68.6 \mathrm{~cm}$ long and weighed 260 grams, whereas at hibernaculum 2 the smallest gravid female was $68.5 \mathrm{~cm}$ long and weighed 285 grams (Table 2). To estimate the age at first reproduction we considered two gravid females with complete rattles that were known to be gravid for the first time based on length and mark recapture history. Two females with complete rattles possessed eight rattle segments plus the button when we determined they were gravid. We can conservatively estimate the age of first reproduction based on the assumption that if these 
females shed twice a year since their birth they would be approximately four years of age when they mated and approximately five years of age at parturition. At the upper limit we estimate that if these females shed only once per year since their birth they would be in their eighth year when they mated and in their ninth year at parturition.

The variable "Female \#" which appears in Tables 2, 4, 5 and 6 refers to specific females whose identification number is listed in Appendix 1 and 2 in association with their hibernaculum of origin and reproductive history.

Table 2. Variation in size of female prairie rattlesnakes at first reproduction.

\begin{tabular}{|c|c|c|c|c|}
\hline Hibernaculum & Female \# & $\begin{array}{c}\text { SVL } \\
(\mathrm{cm})\end{array}$ & $\begin{array}{c}\text { Mass } \\
(\mathrm{g})\end{array}$ & Ova \\
\hline 1 & 5 & 82.0 & 406 & 9 \\
\hline 1 & 6 & 82.9 & 360 & 8 \\
\hline 1 & 25 & 68.6 & 260 & 6 \\
\hline Mean \pm SD & & $77.8 \pm 8.0$ & $342.0 \pm 74.6$ & $7.7 \pm 1.5$ \\
\hline 2 & 5 & 68.5 & 285 & 7 \\
\hline 2 & 28 & 83.2 & 358.5 & 8 \\
\hline Mean \pm SD & & $75.9 \pm 10.4$ & $321.8 \pm 52.0$ & $7.5 \pm 0.7$ \\
\hline
\end{tabular}

\subsection{Reproductive frequency}

The counts of gravid to non-gravid females varied greatly across years at each site and often included the same females. At hibernaculum 1, counts of gravid to non-gravid females were 13:7, 2:19 and 9:9 in 2004, 2005 and 2006 respectively resulting in ratios that varied from $0.1: 1$ to nearly $2: 1$. At hibernaculum 2, counts were $10: 4,3: 15$ and $3: 12$ in 2004,2005 and 2006 respectively resulting in ratios ranging from 0.2:1 to 2.5:1.

Table 3. Ratio of gravid to non gravid female prairie rattlesnakes at hibernacula subject to mark-recapture methods.

\begin{tabular}{|l|l|l|}
\hline Year & Hibernaculum 1 & Hibernaculum 2 \\
\hline 2004 & $1.9: 1(65.0 \%$ gravid $)$ & $2.5: 1(71.4 \%$ gravid $)$ \\
\hline 2005 & $0.1: 1(9.5 \%$ gravid $)$ & $0.2: 1(16.7 \%$ gravid $)$ \\
\hline 2006 & $1: 1(50.0 \%$ gravid $)$ & $0.25: 1(25.0 \%$ gravid $)$ \\
\hline
\end{tabular}

The reproductive status of females at hibernacula 1 and 2 from spring 2004 to fall 2006 is reported in Appendices 1 and 2, respectively. Fifty-seven reproductively mature females were captured at least once at hibernacula 1 and 2 (Appendix 1 and 2). Twenty eight mature females were captured and marked at hibernaculum 1 during five mark-recapture sessions and one opportunistic capture period (spring 2006), with three females captured only once and a median of three captures of each female (Range $=1-6$ captures; Appendix 1). Twenty nine mature females were captured and marked at hibernaculum 2 during five mark-recapture sessions, with 14 females captured only once and a median of two captures of each female (Range $=1-4$ captures; Appendix 2). 
Of the 57 mature females captured and marked at the two hibernacula, reproductive frequency could only be determined with certainty for six individuals that were either gravid twice between the spring of 2004 and fall of 2006 or gravid once and carrying enlarged ova in the fall of 2006 (Table 4, 5, 6). All six of the females for which reproductive frequency was known are from hibernaculum 1; three of these females were gravid at a two-year interval and three were gravid at a three-year interval.

Table 4. Change in mass among mature female prairie rattlesnakes of known reproductive frequency from first observed reproduction to second observed reproduction.

\begin{tabular}{|c|c|c|c|c|}
\hline Female \# & $\begin{array}{c}\text { Reproductive } \\
\text { frequency } \\
\text { (years) }\end{array}$ & $\begin{array}{c}\text { Mass 1 } \\
\text { observed } \\
\text { reproduction } \\
(\mathbf{g})\end{array}$ & $\begin{array}{c}\text { Mass 2 } \\
\text { observed } \\
\text { reproduction } \\
(\mathbf{g})\end{array}$ & $\begin{array}{c}\text { Change in } \\
\text { mass } \\
(\mathbf{g})\end{array}$ \\
\hline 1 & 2 & 510 & 446 & -64 \\
\hline 18 & 2 & 487 & 412.5 & -74.5 \\
\hline 20 & 2 & 665 & 592 & -73 \\
\hline Mean +SD & & $554.0 \pm 96.8$ & $483.5 \pm 95.4$ & $-70.5 \pm 5.7$ \\
\hline 22 & 3 & 570 & 629 & 59 \\
\hline 25 & 3 & 260 & 511 & 251 \\
\hline 26 & 3 & 412 & 541 & 129 \\
\hline Mean + SD & & $414.0 \pm 155.0$ & $560.3 \pm 61.3$ & $146.3 \pm 97.2$ \\
\hline
\end{tabular}

Table 5. Change in snout-vent length among mature female prairie rattlesnakes of known reproductive frequency from first observed reproduction to second observed reproduction.

\begin{tabular}{|c|c|c|c|c|}
\hline Female \# & $\begin{array}{c}\text { Reproductive } \\
\text { frequency } \\
\text { (years) }\end{array}$ & $\begin{array}{c}\text { SVL 1 } \\
\text { observed } \\
\text { reproduction } \\
\text { (cm) }\end{array}$ & $\begin{array}{c}\text { SVL 2 } \\
\text { observed } \\
\text { reproduction } \\
\text { (cm) }\end{array}$ & $\begin{array}{c}\text { Change in } \\
\text { SVL } \\
\text { (cm) }\end{array}$ \\
\hline 1 & 2 & 88.4 & 86.4 & -2 \\
\hline 18 & 2 & 82.3 & 88.4 & 6.1 \\
\hline 20 & 2 & 94.5 & 95.0 & 0.5 \\
\hline Mean +SD & & $88.4 \pm 6.1$ & $89.9 \pm 4.5$ & $1.5 \pm 4.1$ \\
\hline 22 & 3 & 85.1 & 94.7 & 9.6 \\
\hline 25 & 3 & 68.6 & 84.2 & 15.6 \\
\hline 26 & 3 & 77.0 & 89.5 & 12.5 \\
\hline Mean \pm SD & & $76.9 \pm 8.3$ & $89.5 \pm 5.3$ & $12.6 \pm 3.0$ \\
\hline
\end{tabular}


Table 6. Difference in litter size between first and second observed reproduction in relation to reproductive frequency of female prairie rattlesnakes at hibernaculum 1.

\begin{tabular}{|c|c|c|c|c|c|}
\hline Female \# & $\begin{array}{c}\text { Reproductive } \\
\text { frequency } \\
\text { (years) }\end{array}$ & $\begin{array}{c}\text { Ova at 1 } \\
\text { reproduction }\end{array}$ & $\begin{array}{c}\text { Ova at 2 } \\
\text { reproduction }\end{array}$ & Difference & Ova/year \\
\hline 1 & 2 & 10 & 10 & 0 & 10 \\
\hline 18 & 2 & 10 & 7 & -3 & 8.5 \\
\hline 20 & 2 & 12 & 7 & -5 & 9.5 \\
\hline Mean \pm SD & & $10.7 \pm 1.2$ & $8.0 \pm 1.7$ & $-2.7 \pm 2.5$ & $9.3 \pm 0.8$ \\
\hline 22 & 3 & 9 & 11 & 2 & 6.7 \\
\hline 25 & 3 & 6 & 8 & 2 & 4.7 \\
\hline 26 & 3 & 7 & 9 & 2 & 5.3 \\
\hline Mean \pm SD & & $7.3 \pm 1.5$ & $9.3 \pm 1.5$ & 2 & $5.6 \pm 1.0$ \\
\hline
\end{tabular}

The mean snout-vent length of gravid females reproducing at a two year interval and that of females reproducing at a three year interval was not significantly different during the first observed reproduction, nor was it significantly different during the second observed reproduction (Table 5). The same was true of the mean mass during both pregnancies (Table 4). Females reproducing at a three year interval grew significantly more between pregnancies than individuals reproducing at a two year interval $(\mathrm{t}=-3.73, \mathrm{p}=0.02, \mathrm{df}=$ 4). However, accounting for the difference in the number of years over which this growth took place there was no significant difference $(t=-2.58, p=0.06, d f=4)$. Females reproducing at two year intervals weighed less during their second observed reproduction than they did during their first but this difference was not significant $(t=0.89, p=0.41$, $\mathrm{df}=4$ ). Females reproducing at three year intervals weighed more during their second observed reproduction than they did during their first but this difference was also not significant $(\mathrm{t}=-1.52, \mathrm{p}=0.20, \mathrm{df}=4)$.

During their first observed reproduction females reproducing at a two year interval carried significantly more ova than females reproducing at a three year interval $(t=3.07$, $\mathrm{p}=0.04, \mathrm{df}=4$, Table 6 ). There was no significant difference in the number of ova carried by the two classes during their second observed reproduction $(t=-0.98, p=0.38$, $\mathrm{df}=4$ ). Females reproducing at a two year interval carried an average of $2.7 \pm 2.5$ fewer ova during the second observed reproduction than they did during the first, while females reproducing at a three year interval carried an average of 2 more ova. The number of ova produced per year by a female reproducing at a two year interval was significantly greater than the number of ova produced per year by a female reproducing at a three year interval $(\mathrm{t}=5.13, \mathrm{p}=0.007, \mathrm{df}=4)$.

\subsection{Rookery locations and the timing of reproduction}

Twelve rookeries were identified in association with three hibernacula based on the presence of gravid females during the active season or neonates during parturition, or both (Table 7). All twelve rookeries were within $500 \mathrm{~m}$ of known hibernacula. In one instance a female was observed to use a hibernaculum as a rookery. The composition and 
location of rookeries appeared to be largely dependent on local conditions and opportunities available in the vicinity of the hibernaculum. At hibernaculum 1 several rookeries were associated with large sedimentary rocks which were common in this area (Figure 1); however, one rookery consisted of an opening in a slump block near the river. Few large rocks occurred in the area surrounding hibernaculum 2 and abandoned mammal burrows generally served as rookeries (Figure 2). The aspect of rookeries also appeared to vary greatly depending upon where suitable rocks, burrows and cover were located. Despite a great deal of variation in aspect it is likely that micro-site conditions are similar among sites, as all of the sites appeared to offer excellent protection from prevailing winds, and prolonged exposure to the sun in close proximity to secure cover. Rookeries did not tend to occur in any consistent bearing from hibernacula but did tend to occur either within the riparian area or along valley breaks. Some gravid females moved between rookeries during gestation while others remained at a single site until parturition.

A large number of females were gravid at hibernaculum 1 and hibernaculum 2 in 2004 and this facilitated the characterization of some aspects of the timing of their reproductive activities. At hibernaculum 1, we began capturing dispersing gravid females in funnel traps at drift fences on 26 April and the last gravid female was caught while dispersing on 4 June. The first gravid female was detected at a rookery associated with hibernaculum 1 on 2 May. Rookeries at hibernaculum 1 were occupied by as few as one gravid female and as many as four. The first neonates were observed at a rookery on 18 August. The greatest number of neonates counted at a single rookery at any one time was 18 and this site was occupied by four gravid females. During a daily count of neonates on 26 August the greatest number of neonates counted was 34 occurring at four rookeries. At hibernaculum 2 we began capturing dispersing gravid females in funnel traps on 25 April and the last gravid female was captured while dispersing on 3 May. The first rookery occurring in association with hibernaculum 2 was identified on 22 July. The number of gravid females at any single rookery ranged from one to two. The first neonates were observed at two rookeries on 6 September. The greatest number of neonates counted at a single rookery at any one time was six, and the most neonates observed on a single day was 13 occurring at three rookeries on 12 September.

Table 7. Location of rookeries in relation to hibernacula.

\begin{tabular}{|c|c|c|c|}
\hline Hibernaculum & $\begin{array}{c}\text { No. of known } \\
\text { rookeries }\end{array}$ & $\begin{array}{c}\text { Distance from } \\
\text { hibernaculum } \\
(\mathbf{m} \pm \mathbf{S D})\end{array}$ & $\begin{array}{c}\text { Range of distances from } \\
\text { hibernaculum }(\mathbf{m})\end{array}$ \\
\hline 1 & 5 & $251 \pm 147$ & $0-449$ \\
\hline 2 & 5 & $210 \pm 150$ & $123-477$ \\
\hline 3 & 2 & $156 \pm 58$ & $91-173$ \\
\hline
\end{tabular}




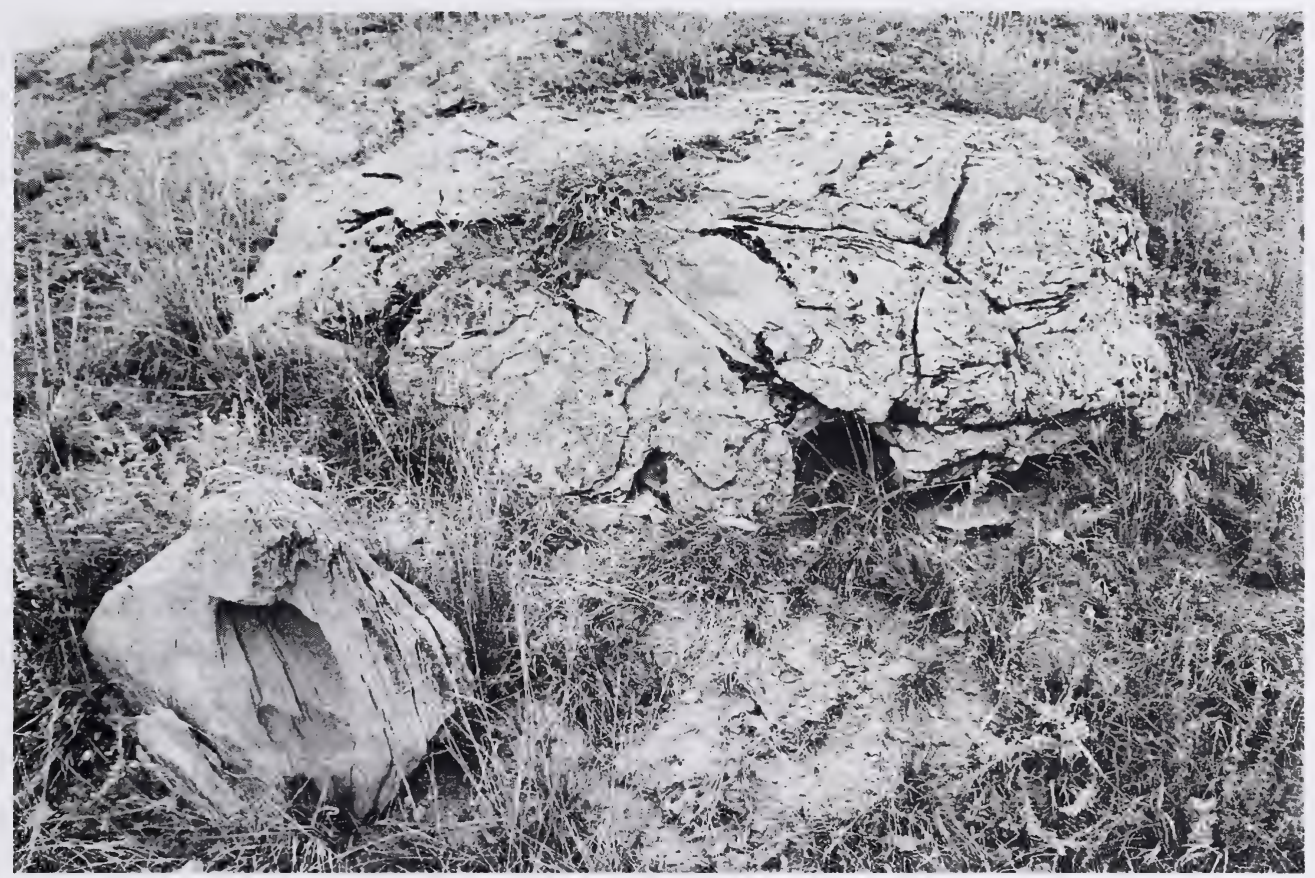

Figure 1. A rookery consisting of a sedimentary table rock approximately 2 metres in diameter with an opening at its base providing access to shelter beneath the rock.

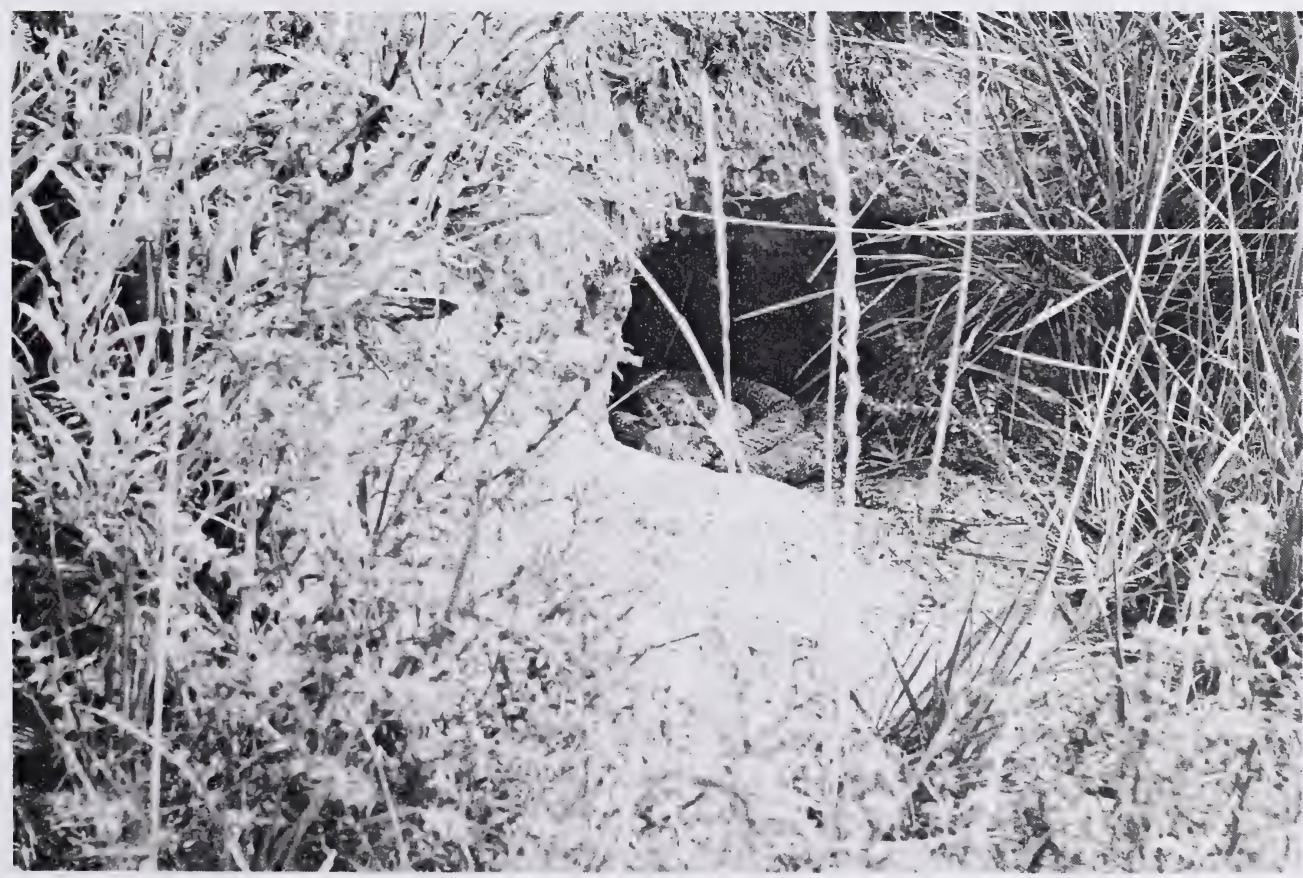

Figure 2. A rookery consisting of an abandoned mammal burrow dug in a sandy substrate. The mouth of this hibernaculum was approximately $20 \mathrm{~cm}$ in diameter. 


\subsection{DISCUSSION}

\section{$\underline{5.1 \text { Characteristics of gravid females }}$}

Gravid females at our study sites in Alberta were shorter, on average, than those studied by Gannon and Secoy (1984) in Saskatchewan (1976: mean $=97.6 \mathrm{~cm}, \mathrm{~N}=33 ; 1977$ : mean $=96.5 \mathrm{~cm}, \mathrm{~N}=20$; range 76.8 to $115.0 \mathrm{~cm})$, but longer than gravid females studied by Graves and Duvall (1993) in Wyoming (mean $=73.2 \pm 0.79, \mathrm{~N}=68$ ). The mean snout-vent length and mass of gravid females was relatively consistent among hibernacula within our study, although hibernacula where fewer gravid females were sampled tended to encompass a narrower range of lengths and masses.

Mean litter sizes were relatively consistent among hibernacula sampled in this study, varying from approximately 8 to 9.5 with a range of 4 to 13 developing ova or embryos per mature female. Powell et al. (1997) observed a similar range of litter sizes among gravid females at a nearby study site in southeastern Alberta (1-13 young, median $=7$ ). Litter sizes in Alberta are larger than those reported for gravid females studied by Kissner et al. (1996) in Grasslands National Park Saskatchewan ( $6.8 \pm 1.6$ neonates) but smaller than those reported by Macartney and Weichel (1993) in the west block of Grasslands National Park in terms of both absolute number $(10.2 \pm 2.6, n=25)$ and the range of litter sizes (8-16 young). Consistent with the later results and overlapping with our own results, an earlier study conducted by Gannon and Secoy (1984) on a northern sub-population of prairie rattlesnakes near Leader Saskatchewan reported litter sizes of $10.2 \pm 0.6$ in 1976 and $9.0 \pm 0.8$ in 1977. In contrast to Canadian populations of prairie rattlesnakes, Graves and Duvall (1993) determined that the mean number of mature ova per pregnant female in Wyoming was $5.2 \pm 2.6, \mathrm{n}=51$. As is common in most snake populations their data showed that larger snakes produce larger litters than smaller snakes, which is consistent with our observation that prairie rattlesnakes in Alberta and Saskatchewan, which are typically larger than those in Wyoming, also appear to produce larger litters.

The percent mass lost at parturition was consistent between hibernacula 1 and 2 in terms of both mean mass lost and the range of observed losses. These values are comparable to the $37 \%$ loss of mass at parturition reported for Crotalus oreganus in British Columbia (Macartney and Gregory 1988).

\section{$\underline{5.2 \text { Size and age at first reproduction }}$}

The smallest sexually mature female identified in our study measured $68.5 \mathrm{~cm}$ long with a second sexually mature female measuring $68.6 \mathrm{~cm}$ long. The smallest sexually mature female encountered by Graves and Duvall (1993) in Wyoming measured only $62.0 \mathrm{~cm}$. While in Saskatchewan, Kissner et al. (1996) found that the smallest female containing enlarged ova or embryos measured $70.5 \mathrm{~cm}$. 
Age at sexual maturity among females at our study site was liberally estimated to be between four and eight years of age. Our observations of variation in size at sexual maturity are consistent with those of Macartney and Weichel (1993). Their study of prairie rattlesnakes found that one female was sexually mature at $78.5 \mathrm{~cm}$ having mated at the end of her third or fourth growing season, but most (23 of 25) gravid females were greater than $83.0 \mathrm{~cm}$ long and would be sexually mature at four or five years of age, producing litters at five or six years of age. Similarly we observed that two females reproducing for the first time were relatively small $(68.5$ and $68.6 \mathrm{~cm})$ but the only other females known to be reproducing for the first time measured between 82.0 and $83.2 \mathrm{~cm}$ (Table 2). There were a number of gravid females intermediate in size (between 68.5 and $83.2 \mathrm{~cm}$ long) that were suspected to be gravid for the first time, but because their reproductive histories were incomplete we could not determine this with certainty. Our estimate was also consistent with the findings of Macartney et al. (1990) who estimated that female $C$. oreganus in British Columbia mature at 5 to 7 years of age $(65.0 \mathrm{~cm})$ and have their first litter at 7 to 9 years of age $(70.0$ to $76.0 \mathrm{~cm})$.

\subsection{Reproductive frequency}

Prairie rattlesnakes were generally thought to reproduce annually across their range until Rahn (1942) showed evidence of a two-year reproductive cycle among mature female Crotalus viridis viridis in Wyoming based on his examination of mature female specimens. Behavioural studies of prairie rattlesnakes supported the hypothesis that the reproductive cycle is superannual, observing that rookeries and foraging areas are spatially separated and that each are attended by only a portion of mature females in a given year (Duvall et al. 1985; Graves and Duvall 1993).

Counts using the ratio of gravid to non-gravid mature females to estimate reproductive frequency have lead researchers to conclude that the reproductive cycle among mature female prairie and western rattlesnakes is biennial, triennial or quadrennial (Macartney and Gregory 1988; King and Duvall 1990; Graves and Duvall 1993; Macartney and Weichel 1993; Kissner et al. 1996). The counts of gravid to non-gravid mature females captured by Graves and Duvall (1993) in Wyoming were 10:10, 9:8, 10:6, 11:52, and 14:27 for 1982, 1983, 1984, 1986, and 1987, respectively. These samples suggest statistically significant differences in proportions of females of adult size that are pregnant between years. Similarly the ratio of gravid to non-gravid females of adult size sampled in our study fluctuated widely between years at both hibernacula. For example, at hibernaculum 1, two thirds of the females of adult size were gravid in 2004 while only approximately one tenth of them were gravid in 2005 (Table 3). The ratio of gravid to non gravid females was highest at hibernaculum 1 and 2 in 2004 and lowest in 2005. Considering that most females at each site were marked and recaptured, and assuming that reproduction is typically not annual, it is not unexpected that few females were gravid in 2005 because the majority of females were gravid in 2004.

In contrast, Kissner et al. (1996) found that gravid female prairie rattlesnakes consistently represented approximately half of all females of adult size: 46:29 (61\% gravid), 27:21 
(56\% gravid), and 11:14 (44\% gravid) in the fall of 1994, the spring of 1995 and the fall of 1995 respectively. In a study of the same population Macartney and Weichel (1993) pooled their data for mature females at all hibernacula in their study area (SVL $>830$ $\mathrm{mm}, \mathrm{n}=40$ ). They calculated a ratio for gravid to non-gravid females of $0.6: 1$ suggesting that the reproductive cycle is at least biennial. Two other studies conducted on this population also found that approximately $50 \%$ of females of adult size were gravid in a given year (Gannon and Secoy 1985; Macartney and Weichel 1989) supporting the suggestion that the female reproductive cycle is at least biennial. Nonetheless Kissner et al. (1996) did capture four mature females that were gravid in the fall of both 1994 and 1995 indicating that some females in this population are capable of annual reproduction.

In another study of prairie rattlesnakes in Wyoming, King and Duvall (1990) captured 26 gravid females and 56 non-gravid females as they emerged from hibernacula between 1982 and 1984. The resulting ratio lead King and Duvall (1990) to speculate that a triennial reproductive cycle is most typical of mature females at their study site, a position that they felt was strengthened by the fact that they collected samples over several successive seasons. However, if we compare this with Graves and Duvall (1993) who also sampled in Wyoming from 1982 to 1984 but also sampled in 1986 and 1987, we find that the counts of 1986 (11:52) and 1987 (14:27) in isolation would result in a completely different estimate of reproductive frequency.

It appears that when ratios of gravid to non-gravid mature females within a population are compared over several consecutive years they are rarely consistent (e.g. Graves and Duvall 1993), and therefore this approach cannot be considered a reliable means of estimating the reproductive frequency of a population, particularly in short-term studies where the potential range of variation may not be represented. At a study site such as our own where we likely captured the majority of mature females at our fenced hibernacula, it is not surprising that if most females are gravid one year, then most will not be gravid in the next, because annual reproduction is uncommon. In cases where numbers of gravid and non-gravid females were approximately equal over several sampling periods, high prey availability could allow for more females with a biennial rather than triennial reproductive cycle. If the reproductive cycle was consistently biennial, equal ratios might be maintained unless the system was perturbed by disturbances contributing to large fluctuation in prey availability (e.g. fire, cultivation).

A potentially more reliable means of determining the reproductive frequency of mature female rattlesnakes is to assess the reproductive status of individuals over several years to follow their reproductive histories, although this can be highly labour intensive, time consuming and potentially disruptive to rattlesnakes, and the outcome may be inconclusive. Of the six mature females for which the reproductive frequency was successfully determined in our study, three exhibited a two year reproductive cycle and three exhibited a three year reproductive cycle. Some females appear capable of recuperating sufficient body fat reserves during a single active season in the year following parturition, resulting in a biennial reproductive cycle, but others exhibiting a triennial reproductive cycle, must have to forego reproduction because of a lack of body fat, and feed for an additional active season (Macartney and Gregory 1988). 
Although we did not determine the typical reproductive frequency of prairie rattlesnakes in southeastern Alberta, the finding that females exhibit both two year and three year reproductive cycles at a single hibernaculum within the same period of time is informative. This observation requires us to consider intrinsic and extrinsic factors that could potentially influence the probability that a female becomes gravid in a given season. Body fat reserves are believed to be critical to reproduction in female rattlesnakes (Blem 1982; Diller and Wallace 1984; Macartney and Gregory 1988; Charland and Gregory 1989; Brown 1991); therefore, foraging success should presumably play a key role in determining reproductive frequency (Aldridge 1979; Charland and Gregory 1989; Macartney and Weichel 1993). Several researchers have suggested that rather than being fixed, reproductive frequency could vary from cycle to cycle depending on the amount of prey available between cycles (Aldridge 1979; Blem 1982, Gannon and Secoy 1984). The ability to secure resources (food and mates) necessary for reproduction could be limited by intrinsic factors such as female size (Blem 1982), which could limit the size of prey consumed or attractiveness to reproductive males; tradeoffs between growth and storage of acquired resources; and behaviours that could be maladaptive. Extrinsic factors are perhaps more likely to limit the ability of a mature female to secure resources, particularly in the northernmost limits of the species' range. These factors may include: intraspecific competition; environmental conditions affecting the amount of time available for foraging (Duvall et al. 1982); environmental conditions that might limit productivity and the availability of prey (Diller and Wallace 1984); and anthropogenic disturbance that might alter the availability of prey, mates and cover. Although we cannot draw any conclusions regarding the contribution of intrinsic and extrinsic factors to variation in reproductive frequency, our work has shown that this variability is indeed observed among individuals in populations of prairie rattlesnakes in Alberta. Additional long-term research is required to determine whether the reproductive frequency of an individual tends to be variable, while also tracking the influence of intrinsic and extrinsic factors that could contribute to variation.

\section{$\underline{5.4 \text { Rookery locations and the timing of reproduction }}$}

All twelve rookeries located during our study were within $500 \mathrm{~m}$ of known hibernacula. Two other studies conducted in Alberta reported dispersion distances for tracked gravid female prairie rattlesnakes. Didiuk (1999) radio-tracked two gravid females from a known hibernaculum in May and June 1995. In that study, gravid females travelled a straight-line distance of approximately 1 kilometre from their respective hibernacula to sites along the banks of the South Saskatchewan River where they used mammal burrows and piles of driftwood for shelter, the later of which would seem to be less permanent than any rookery that we observed. The gravid females tracked by Didiuk travelled approximately twice the straight-line distance from hibernacula than those observed in our study. Fast (2003) radio-tracked one gravid female in southeastern Alberta that was initially captured after it had already left its hibernaculum. In this instance, the location of the hibernaculum was unknown so the maximum displacement of the rattlesnake was estimated based on the furthest perpendicular distance of the snake from the river, which 
was 640 metres and was believed to be an overestimate. In contrast to gravid females that remained in riparian areas or on valley breaks as observed by Didiuk (1999) and our own study, the female tracked by Fast (2003) moved into upland prairie habitat away from the riparian area. In Wyoming, Graves and Duvall (1993) tracked three gravid females from one hibernaculum to three separate rookeries. These three females travelled 540 metres, 30 metres and 600 metres to reach rookeries. Both the observation of multiple rookeries associated with a single hibernaculum and the distances travelled by these gravid females to reach rookeries are relatively consistent with observations from studies in Alberta, although a larger sample from Wyoming would be necessary to determine whether rookeries in Wyoming tend to be further from hibernacula than those in Alberta.

The annual timing of activities of gravid females likely depends on individual variation and variation in environmental conditions. Despite variation in the timing of activities we suggest that our females at rookeries in 2004 should provide a good indication of variation in the timing of dispersion from hibernacula, arrival at rookeries, gestation and parturition.. In our study some gravid females were observed to occupy more than one rookery during gestation. Keenlyne (1972) reported that gravid females may feed infrequently or not at all during gestation. Therefore movement during gestation may provide opportunities for foraging that would not otherwise be available if the rattlesnake remained at a single rookery until parturition, particularly if that hibernaculum sheltered a large aggregation of gravid females. Alternatively, movement between these sites may be the result of perceived threats at one rookery (e.g. predators), resulting in relocation to another site. In one instance a rookery consisting of a burrow in the sand was excavated and destroyed by a coyote (Canis latrans) and the marked female occupying that site was never recaptured suggesting that there are some threats to gravid females occupying rookeries. Regardless, it is apparent that some gravid females seem to be aware of the location of more than one rookery and that these sites may in a sense be considered a network among which the gravid females can move during gestation.

\subsection{RECOMMENDATIONS FOR FUTURE RESEARCH AND MANAGEMENT}

Although we were only able to determine reproductive frequency of six females, a secondary examination of the reproductive histories gathered reveals that no individuals were gravid on an annual basis. Furthermore, annual reproduction appears unlikely in this population considering that many females were non-gravid in the spring and carrying developing ova in the fall, which is indicative of at least a two year reproductive cycle. Therefore regardless of our small sample size, we can state with certainty that reproduction is slow in this species in Alberta, which may limit their ability to recover from direct and indirect environmental pressures. We recommend additional research to quantify direct mortality sustained as a function of human activities (e.g. roads and agriculture), particularly agriculture, the effects of which are less easily measured than road mortality. Knowledge of mortality and reproductive biology of rattlesnakes will allow us to more reliably model the likelihood of persistence of populations in various landscapes throughout southeastern Alberta. 
Rookeries are critical to the survival of both gravid females and neonates that are born at these sites. Rookeries tend to be close to hibernacula, which is likely an adaptation to reduced ability to move and limited energy reserves available to these individuals. Any persistent factors that might compromise the integrity of rookeries, hibernacula or the intervening habitat would certainly have a disproportionate effect on the survival of gravid females and neonates, reducing the likelihood that a population will persist, particularly if other pressures exist (e.g. human caused mortality of migrants). In light of our findings that rookeries typically occur within approximately 500 metres of hibernacula, we recommend that the current setback distances limiting human activities within 200 metres of hibernacula be extended to 500 metres to better ensure the protection of rookeries, hibernacula and the intervening habitat. Furthermore, we recommend that a setback of 200 metres be applied to rookeries occurring greater than 500 metres from a known hibernaculum.

It has been suggested that to locate additional rookeries for future protection, gravid females should be captured at hibernacula after emergence, implanted with radiotransmitters and followed to rookeries (Kissner and Nicholson 2003). We would recommend caution in applying this as a widespread strategy because implantation of radio-transmitters in gravid female prairie rattlesnakes early in the active season is believed to result in resorbed follicles (Graves and Duvall 1993), delaying reproduction by at least one year. The same study found that gravid females implanted with radiotransmitters later in the active season continued pregnancy through parturition. In our research we found that non-gravid females often use rookeries as shelter during initial dispersion from hibernacula revealing the location of aggregations of gravid females. Therefore implantating radio-transmitters with batteries programmed to last at least two active seasons in non-gravid females might be considered an alternative means of identifying rookeries without potentially jeopardizing successful reproduction of gravid females.

Human activities and modifications to the landscape surrounding hibernacula (e.g. roads and cultivation) contribute to increased risk of mortality of prairie rattlesnakes. If in the future measurable declines are documented within populations, and these declines are thought to threaten their persistence, managers should consider supporting research that measures the effects of enhancing habitat that supports common prey items (e.g. deer mice or ground-nesting birds) in the vicinity of hibernacula and rookeries in areas where landscapes have been altered by human activities. In addition, provision of cover (e.g. table rock in a strategic location) in areas where existing rookeries do not offer significant protection from predators (e.g. sand dominated sites) or where rookeries are considered scarce could increase survivorship of gravid females and neonates.

Annual visits to rookeries studied in this report would allow us to accumulate additional data on marked gravid females, providing more detailed information regarding variation in female reproductive characteristics. A low frequency of visits to rookeries is recommended to ensure the integrity and security of these sites is maintained for gestation and parturition. 


\subsection{LITERATURE CITED}

Aldridge, R.D. 1979. Female reproductive cycles of the snakes Arizona elegans and Crotalus viridis. Herpetologica 35: 256-261.

Alberta Sustainable Resource Development. 2006. The General Status of Alberta Wild Species 2005. Alberta Sustainable Resource Development, Fish and Wildlife Division, Edmonton, AB. http://www.srd.gov.ab.ca/fw/wildspecies/index.htm

Blem, C.R. 1982. Biennial reproduction in snakes: an alternative hypothesis. Copeia 1982: 961-963.

Brown, W.S. 1991. Female reproductive ecology in a northern population of the timber rattlesnake, Crotalus horridus. Herpetologica 47: 101-115.

Charland, M.B. and P.T. Gregory. 1989. Feeding rate and weight gain in postpartum rattlesnakes: do animals that eat more always grow more? Copeia 1989: 207-210.

Didiuk, A.B. 1999. Reptile and amphibian component report; Canadian Forces Base Suffield National Wildlife Area, Wildlife Inventory. Canadian Wildlife Service, Environment Canada, Prairie and Northern Region. Edmonton, Alberta. Unpubl. manuscript. $69 \mathrm{pp}$.

Diller, L.V. and R.L. Wallace. 1984. Reproductive biology of the northern Pacific rattlesnake (Crotalus viridis oreganus) in northern Idaho. Herpetologica 40: 182193.

Diller, L.V. and R.L. Wallace. 2002. Growth, reproduction, and survival in a population of Crotalus viridis oreganus in North Central Idaho. Herpetological Monographs 16: $26-45$.

Fast, A. 2003. Models for Predicting the Occurrence of Gravid Prairie Rattlesnake (Crotalus viridis viridis) Habitat and Hibernacula in Alberta. Master's degree project. Faculty of Environmental Design, University of Calgary, Alberta. 76 pp.

Gannon, V.P.J. 1980. Some aspects of the ecology of the Prairie Rattlesnake Crotalus viridis Rafinesque in western Canada. M.Sc. thesis, University of Regina, 79 pp.

Gannon, V.P.J. and D.M. Secoy. 1985. Seasonal and daily activity patterns in a Canadian population of the prairie rattlesnake Crotalus v. viridis. Canadian Journal of Zoology 63: 86-91.

Gannon, V.P.J. and D.M. Secoy. 1984. Growth and reproductive rates of a northern population of the prairie rattlesnake, Crotalus v. viridis . Journal of Herpetology. 81: 13-19. 
Graves, B.M. and D. Duvall. 1993. Reproduction, rookery use, and thermoregulation in free-ranging, pregnant Crotalus v. viridis.

Keenlyne, K.D. 1972. Sexual differences in feeding habits of Crotalus horridus horridus. Journal of Herpetology 6: 234-237.

King, M.B. and D. Duvall. 1990. Prairie rattlesnake seasonal migrations: episodes of movement, vernal foraging and sex differences. Animal Behaviour 39: 924-935.

Kissner, K.J. and J. Nicholson. 2003. Prairie Rattlesnake (Crotalus viridis) Hibernacula: Monitoring History in Alberta 1987-2002. Alberta Sustainable Resource Development, Fish and Wildlife Division, Species at Risk Report No. 76. Edmonton, AB.

Macartney, J.M., Gregory, P.T. and M.B. Charland. 1990. Growth and sexual maturity of the western rattlesnake, Crotalus viridis, in British Columbia. Copeia 1990(2): 528-542.

Macartney, J.M. and P.T. Gregory. 1988. Reproductive biology of female rattlesnakes (Crotalus viridis) in British Columbia. Copeia 1988: 47-57.

Macartney, M. and B. Weichel. 1993. Population status and biology of the prairie rattlesnake and other reptile species in southwest Saskatchewan $1990-1991$. Johnson and Weichel Resource Management Consultants. Final Report: Submitted March 1993

Macartney, J.M. and B. Weichel. 1989. Prairie Rattlesnake survey and management plan. Unpublished report for the Saskatchewan Natural History Society. 44 pp.

MacKay, R. 1987. A survey of snake hibernacula in the Val Marie area. Unpublished report for the Saskatchewan Natural History Society. 14 pp.

Pendlebury, G.B. 1977. Distribution and abundance of the Prairie Rattlesnake, Crotalus viridis, in Canada. Canadian Field-Naturalist 91: 122-129.

Powell, G.L., A.P. Russell, M.M.A. Hill, N.E. O'Brien, and J. Skilnick. 1998. A preliminary investigation of movements, habitat use, and population trends in the prairie rattlesnake (Crotalus viridis) in a multiple-use rural landscape in southeastern Alberta. The 1997 field season. Prepared for the Alberta Conservation Association. Calgary, AB. 20 pp.

Rahn, H. 1942. The reproductive cycle of the prairie rattler. Copeia 1942 (4): 233-240. 


\section{APPENDIX 1}

Capture history and reproductive status of mature females from spring 2004 to fall 2006 at hibernaculum 1

\begin{tabular}{|c|c|c|c|c|c|c|c|c|c|}
\hline $\begin{array}{c}\text { Female } \\
\underset{\#}{ }\end{array}$ & $\begin{array}{c}\text { Spring } \\
04\end{array}$ & $\begin{array}{c}\text { Fall } \\
04\end{array}$ & $\begin{array}{c}\text { Spring } \\
05\end{array}$ & $\begin{array}{c}\text { Fall } \\
05\end{array}$ & $\begin{array}{c}\text { Spring } \\
06\end{array}$ & $\begin{array}{c}\text { Fall } \\
06\end{array}$ & $\begin{array}{c}\text { Reprod. } \\
\text { Freq. } \\
\text { (yrs) }\end{array}$ & $\begin{array}{c}\# \\
\text { captures }\end{array}$ & Comments \\
\hline 1 & GR & NG & NG & DO & $*$ & NG & 2 & 5 & \\
\hline 2 & GR & $*$ & $*$ & $*$ & $*$ & $*$ & & 1 & \\
\hline 3 & NG & $*$ & GR & NG & $*$ & NG & & 4 & \\
\hline 4 & $*$ & $*$ & $*$ & DO & GR & $*$ & & 2 & \\
\hline 5 & NG & NG & NG & $*$ & $*$ & DO & & 4 & $1^{\text {st }}$ reprod. \\
\hline 6 & $*$ & NG & NG & NG & * & DO & & 4 & $1^{\text {st }}$ reprod. \\
\hline 7 & NG & DO & GR & $*$ & $*$ & $*$ & & 3 & \\
\hline 8 & $*$ & $*$ & NG & NG & $*$ & NG & & 3 & \\
\hline 9 & GR & NG & NG & $*$ & $*$ & $*$ & & 3 & \\
\hline 10 & NG & $*$ & $*$ & * & $*$ & $*$ & & 1 & \\
\hline 11 & $*$ & $*$ & NG & DO & $*$ & $*$ & & 2 & \\
\hline 12 & NG & NG & NG & NG & * & $*$ & & 4 & \\
\hline 13 & GR & NG & NG & NG & $*$ & $*$ & & 4 & \\
\hline 14 & GR & NG & NG & $*$ & * & $*$ & & 3 & \\
\hline 15 & $*$ & $*$ & $*$ & DO & $*$ & $*$ & & 1 & \\
\hline 16 & GR & NG & $*$ & $*$ & $*$ & $*$ & & 2 & \\
\hline 17 & GR & $*$ & NG & NG & NG & $*$ & & 4 & \\
\hline 18 & GR & NG & NG & DO & $*$ & NG & 2 & 5 & \\
\hline 19 & GR & NG & $*$ & $*$ & $*$ & $*$ & & 2 & \\
\hline 20 & GR & $*$ & NG & DO & $*$ & $*$ & 2 & 3 & \\
\hline 21 & NG & NG & NG & DO & $*$ & NG & & 5 & \\
\hline 22 & GR & NG & NG & NG & NG & DO & 3 & 6 & \\
\hline 23 & $*$ & $*$ & NG & DO & $*$ & $*$ & & 2 & \\
\hline 24 & NG & $*$ & $*$ & DO & GR & NG & & 4 & \\
\hline 25 & GR & NG & NG & $*$ & $*$ & DO & 3 & 4 & $1^{\text {st }}$ reprod. \\
\hline 26 & GR & NG & NG & NG & NG & DO & 3 & 6 & \\
\hline 27 & $*$ & $*$ & $*$ & NG & $*$ & DO & & 2 & \\
\hline 28 & * & * & $*$ & DO & GR & * & & 2 & \\
\hline
\end{tabular}

$\mathrm{NG}=$ Non-gravid $; \mathrm{GR}=$ Gravid $; \mathrm{DO}=$ Developing ova $; *$ = not captured during this session; $1^{\text {st }}$ reprod. $=$ 


\section{APPENDIX 2}

Capture history and reproductive status of mature females from spring 2004 to fall 2006 at hibernaculum 2

\begin{tabular}{|c|c|c|c|c|c|c|c|}
\hline $\begin{array}{c}\text { Female } \\
\#\end{array}$ & $\begin{array}{c}\text { Spring } \\
04\end{array}$ & $\begin{array}{c}\text { Fall } \\
04\end{array}$ & $\begin{array}{c}\text { Spring } \\
05\end{array}$ & $\begin{array}{l}\text { Fall } \\
05\end{array}$ & $\begin{array}{c}\text { Fall } \\
06\end{array}$ & $\begin{array}{c}\# \\
\text { captures }\end{array}$ & Comments \\
\hline 1 & $*$ & $*$ & GR & NG & $*$ & 2 & \\
\hline 2 & GR & NG & NG & $*$ & * & 3 & \\
\hline 3 & GR & NG & NG & NG & * & 4 & \\
\hline 4 & GR & $*$ & NG & NG & * & 3 & \\
\hline 5 & GR & NG & NG & NG & $*$ & 4 & $1^{\text {st }}$ reprod. \\
\hline 6 & GR & NG & NG & NG & $*$ & 4 & \\
\hline 7 & $*$ & $*$ & NG & NG & $*$ & 2 & \\
\hline 8 & * & * & $*$ & NG & * & 1 & \\
\hline 9 & $*$ & NG & $*$ & DO & * & 2 & \\
\hline 10 & NG & DO & GR & $*$ & $*$ & 3 & \\
\hline 11 & $*$ & $*$ & NG & $*$ & $*$ & 1 & \\
\hline 12 & $*$ & NG & $*$ & DO & $*$ & 2 & \\
\hline 13 & NG & NG & NG & $*$ & $*$ & 3 & \\
\hline 14 & $*$ & NG & NG & $*$ & * & 2 & \\
\hline 15 & GR & $*$ & $*$ & $*$ & * & 1 & \\
\hline 16 & GR & $*$ & $*$ & $*$ & $*$ & 1 & \\
\hline 17 & $*$ & NG & $*$ & $*$ & $*$ & 1 & \\
\hline 18 & $*$ & $*$ & $*$ & DO & $*$ & 1 & \\
\hline 19 & NG & $*$ & $*$ & NG & $*$ & 2 & \\
\hline 20 & $*$ & NG & $*$ & $*$ & $*$ & 1 & \\
\hline 21 & $*$ & $*$ & $*$ & NG & $*$ & 1 & \\
\hline 22 & GR & * & * & * & * & 1 & \\
\hline 23 & $*$ & * & * & NG & * & 1 & \\
\hline 24 & GR & NG & $*$ & $*$ & $*$ & 2 & \\
\hline 25 & $*$ & $*$ & $*$ & NG & * & 1 & \\
\hline 26 & * & * & GR & $*$ & * & 1 & \\
\hline 27 & GR & $*$ & $*$ & $*$ & $*$ & 1 & \\
\hline 28 & NG & NG & * & DO & $*$ & 3 & $1^{\text {st }}$ reprod. \\
\hline 29 & $*$ & $*$ & $*$ & NG & $*$ & 1 & \\
\hline
\end{tabular}

$\mathrm{NG}=$ Non-gravid; GR $=$ Gravid; DO = Developing ova $; *$ = not captured during this session. Note: trapping was not conducted at hibernaculum 2 during the spring of 2006 


\section{List of Titles in This Series}

(as of January 2007)

No. 1 Alberta species at risk program and projects 2000-2001, by Alberta Sustainable Resource Development, Fish and Wildlife Division. (2001)

No. 2 Survey of the peregrine falcon (Falco peregrinus anatum) in Alberta, by R. Corrigan. (2001)

No. 3 Distribution and relative abundance of the shortjaw cisco (Coregonus zenithicus) in Alberta, by M. Steinhilber and L. Rhude. (2001)

No. 4 Survey of the bats of central and northwestern Alberta, by M.J. Vonhof and D. Hobson. (2001)

No. 52000 survey of the Trumpeter Swan (Cygnus buccinator) in Alberta, by M.L. James and A. James. (2001)

No. 6 2000/2001 Brassy Minnow inventory at Musreau Lake and outlet, by T. Ripley. (2001)

No. 7 Colonial nesting waterbird survey in the Northwest Boreal Region - 2000, by M. Hanneman and M. Heckbert. (2001)

No. 8 Burrowing owl trend block survey and monitoring - Brooks and Hanna areas, by D. Scobie and R. Russell. (2000)

No. 9 Survey of the Lake Sturgeon (Acipenser fulvescens) fishery on the South Saskatchewan River, Alberta (June-September, 2000), by L.A. Winkel. (2000)

No. 10 An evaluation of grizzly bear-human conflict in the Northwest Boreal Region of Alberta (19912000) and potential mitigation, by T. Augustyn. (2001)

No. 11 Harlequin duck monitoring in the Northern East Slopes of Alberta: 1998-2000 preliminary results, by J. Kneteman and A. Hubbs. (2000)

No. 12 Distribution of selected small mammals in Alberta, by L. Engley and M. Norton. (2001)

No. 13 Northern leopard frog reintroduction. Raven River - Year 2 (2000), by K. Kendell. (2001)

No. 14 Cumulative effects of watershed disturbances on fish communities in the Kakwa and Simonette watersheds. The Northern Watershed Project. Study 3 Progress report, by T. Thera and A. Wildeman. (2001)

No. 15 Harlequin duck research in Kananaskis Country in 2000, by C.M. Smith. (2001)

No. 16 Proposed monitoring plan for harlequin ducks in the Bow Region of Alberta, by C.M. Smith. (2001)

No. 17 Distribution and relative abundance of small mammals of the western plains of Alberta as determined from great horned owl pellets, by D. Schowalter. (2001)

No. 18 Western blue flag (Iris missouriensis) in Alberta: a census of naturally occurring populations for 2000, by R. Ernst. (2000)

No. 19 Assessing chick survival of sage grouse in Canada, by C.L. Aldridge. (2000)

No. 20 Harlequin duck surveys of the Oldman River Basin in 2000, by D. Paton. (2000) 
No. 21 Proposed protocols for inventories of rare plants of the Grassland Natural Region, by C. Wallis. (2001)

No. 22 Utilization of airphoto interpretation to locate prairie rattlesnake (Crotalus viridis viridis) hibernacula in the South Saskatchewan River valley, by J. Nicholson and S. Rose. (2001)

No. 23 2000/2001 Progress report on caribou research in west central Alberta, by T. Szkorupa. (2001)

No. 24 Census of swift fox (Vulpes velox) in Canada and Northern Montana: 2000-2001, by A. Moehrenschlager and C. Moehrenschlager. (2001)

No. 25 Population estimate and habitat associations of the long-billed curlew in Alberta, by E.J. Saunders. (2001)

No. 26 Aerial reconnaissance for piping plover habitat in east-central Alberta, May 2001, by D.R.C. Prescott. (2001)

No. 27 The 2001 international piping plover census in Alberta, by D.R.C. Prescott. (2001)

No. 28 Prairie rattlesnake (Crotalus viridis viridis) monitoring in Alberta - preliminary investigations (2000), by S.L. Rose. (2001)

No. 29 A survey of short-horned lizard (Phrynosoma hernandesi hernandesi) populations in Alberta, by J. James. (2001)

No. 30 Red-sided garter snake (Thamnophis sirtalis parietalis) education and relocation project - final report, by L. Takats. (2002)

No. 31 Alberta furbearer harvest data analysis, by K.G. Poole and G. Mowat. (2001)

No. 32 Measuring wolverine distribution and abundance in Alberta, by G. Mowat. (2001)

No. 33 Woodland caribou (Rangifer tarandus caribou) habitat classification in northeastern Alberta using remote sensing, by G.A. Sanchez-Azofeifa and R. Bechtel. (2001)

No. 34 Peregrine falcon surveys and monitoring in the Parkland Region of Alberta, 2001, by R. Corrigan. (2002)

No. 35 Protocol for monitoring long-toed salamander (Ambystoma macrodactylum) populations in Alberta, by T. Pretzlaw, M. Huynh, L. Takats and L. Wilkinson. (2002)

No. 36 Long-toed salamander (Ambystoma macrodactylum) monitoring study in Alberta: summary report 1998-2001, by M. Huynh, L. Takats and L. Wilkinson. (2002)

No. 37 Mountain plover habitat and population surveys in Alberta, 2001, by C. Wershler and C. Wallis. (2002)

No. 38 A census and recommendations for management for western blue flag (Iris missouriensis) in Alberta, by R. Ernst. (2002)

No. 39 Columbian mountain amphibian surveys, 2001, by D. Paton. (2002)

No. 40 Management and recovery strategies for the Lethbridge population of the prairie rattlesnake, by R. Ernst. (2002) 
No. 41 Western (Aechmophorus occidentalis) and eared (Podiceps nigricollis) grebes of central Alberta: inventory, survey techniques and management concerns, by S. Hanus, H. Wollis and L. Wilkinson. (2002)

No. 42 Northern leopard frog reintroduction - year 3 (2001), by K. Kendell. (2002)

No. 43 Survey protocol for the northern leopard frog, by K. Kendell. (2002)

No. 44 Alberta inventory for the northern leopard frog (2000-2001), by K. Kendell. (2002)

No. 45 Fish species at risk in the Milk and St. Mary drainages, by RL\&L Environmental Services Ltd. (2002)

No. 46 Survey of the loggerhead shrike in the southern aspen parkland region, 2000-2001, by H. Kiliaan and D.R.C. Prescott. (2002)

No. 47 Survey of native grassland butterflies in the Peace parkland region of northwestern Alberta - 2001, by M. Hervieux. (2002)

No. 48 Caribou range recovery in Alberta: 2001/02 pilot year, by T. Szkorupa. (2002)

No. 49 Peace parkland native grassland stewardship program 2001/02, by A. Baker. (2002)

No. 50 Carnivores and corridors in the Crowsnest Pass, by C. Chetkiewicz. (2002)

No. 512001 Burrowing owl trend block survey and monitoring, Brooks and Hanna areas, by D. Scobie. (2002)

No. 52 An evaluation of the ferruginous hawk population in Alberta based on recent trend data, by D.P. Stepnisky, G.L. Erickson, J. Iwaasa and B. Taylor. (2002)

No. 53 Alberta amphibian call surveys. A pilot year. Final report, by L. Takats and C. Priestley. (2002)

No. 54 Utilization of a roadside survey technique to survey burrowing owl (Athene cunicularia hypugaea) in southeastern Alberta, by J. Nicholson and C. Skiftun. (2002)

No. 55 Alberta species at risk program and projects 2001-2002, by Alberta Sustainable Resource Development, Fish and Wildlife Division. (2002)

No. 56 Developing a habitat-based population viability model for greater sage-grouse in southeastern Alberta, by C.L. Aldridge. (2001)

No. 57 Peregrine falcon surveys and monitoring in the Northeast Boreal Region of Alberta, 2001, by R. Corrigan. (2002)

No. 582002 burrowing owl trend block survey and monitoring, Brooks area, by R.F. Russell. (2002)

No. 59 Rare plant inventory of the eastern edge of the lower foothills natural subregion, west-central Alberta, by J. Doubt. (2002)

No. 60 Western (Aechmophorus occidentalis) and eared (Podiceps nigricollis) grebes of central Alberta: 2002 field summary, by S. Hanus, L. Wilkinson and H. Wollis. (2002)

No. 61 Inventory of western spiderwort (Tradescantia occidentalis) in Alberta: 2002, by S. Peters. (2003) 
No. 62 Bullsnakes (Pituophis catenifer sayi) in Alberta: literature review and data compilation, by K.J. Kissner and J. Nicholson. (2003)

No. 63 Distribution of Ord's kangaroo rats in southeastern Alberta, by D.L. Gummer and S.E. Robertson. (2003)

No. 64 Lethbridge prairie rattlesnake conservation project: 2002/2003 progress report, by R.D. Ernst. (2003)

No. 65 Short-horned lizard (Phrynosoma hernandesi hernandesi) populations in Alberta - 2002 survey results, by J.D. James. (2003)

No. 66 Inventory and monitoring protocol for naturally occurring western blue flag (Iris missouriensis) in Alberta, by R.D. Ernst. (2003)

No. 67 The use of call playbacks for censusing loggerhead shrikes in southern Alberta, by D.R.C. Prescott. (2003)

No. 68 Survey of bats in northeastern Alberta, by A. Hubbs and T. Schowalter. (2003)

No. 69 Survey protocol for the Richardson's ground squirrel, by B.A. Downey. (2003)

No. 70 Population estimates and a survey protocol for ferruginous hawks in Alberta, by B.N. Taylor. (2003)

No. 71 Testing methods for detecting wolverine, by G. Mowat, C. Kyle and D. Paetkau. (2003)

No. 72 A multi-species conservation strategy for species at risk in the Milk River basin: year 1 progress report, by R.W. Quinlan, B.A. Downey, B.N. Taylor, P.F. Jones and T.B. Clayton. (2003)

No. 73 Long-toed salamander (Ambystoma macrodactylum) conservation in the Alberta foothills: 2002 field summary report, by L. Wilkinson and S. Hanus. (2003)

No. 74 Researching Amphibian Numbers in Alberta (RANA): 2002 provincial summary, by L. Wilkinson and S. Hanus. (2003)

No. 75 Distribution and habitat associations of the long-toed salamander (Ambystoma macrodactylum) in the Oldman River drainage, by K. Pearson. (2003)

No. 76 Prairie rattlesnake (Crotalus viridis) hibernacula: monitoring history in Alberta 1987-2002, by K.J. Kissner and J. Nicholson. (2003)

No. 77 Alberta species at risk program and projects 2002-2003, by Alberta Sustainable Resource Development, Fish and Wildlife Division. (2003)

No. 78 Northern leopard frog reintroduction: Year 4 (2002), by K. Kendell. (2003)

No. 79 Magrath Northern Leopard Frog Reintroduction Project - Year 1 Progress Report, by K.A. Romanchuck. (2003)

No. 80 Conservation Overview of Butterflies in the Southern Headwaters at Risk Project (SHARP) Area, by N. Kondla. (2004)

No. 81 Lethbridge Rattlesnake Conservation Project: 2003 Progress Report, by R. Ernst. (2004)

No. 82 Shortjaw Cisco Species at Risk Assessment 2001, by M. Steinhilber. (2004) 
No. 83 Researching Amphibian Numbers in Alberta (RANA): 2003 provincial summary, by L. Wilkinson and K. Kempin. (2004)

No. 84 Methods for Controlling Depredation on Piping Plovers in Alberta: A Literature Review and Synthesis, by R. Schmelzeisen, D.R.C. Prescott and L. Engley. (2004)

No. 85 Western Blue Flag Conservation Program: 3-Year Summary Report, by K.A. Romanchuk, R.D. Ernst, and R.W Quinlan (2004)

No. 86 MULTISAR: The Milk River Basin Habitat Suitability Models for Selected Wildlife Management Species, by B. A. Downey, B. L. Downey, R. W. Quinlan, O. Castelli, V. Remesz and P. F. Jones (eds.). (2004)

No. 87 MULTISAR: The Milk River Basin, A Multi-Species Conservation Strategy For Species at Risk: Year 2-Progress Report, by R.W. Quinlan, B. A. Downey, B. L. Downey, and P. F. Jones. (2004)

No. 88 Survey of Colonial Nesting Birds and Lakeshore Habitats in Northeast Alberta, by C. Found and A. Hubbs. (2004)

No. 89 The southern headwaters at risk project: A multi-species conservation strategy for the headwaters of the Oldman River. Volume 1: Introduction and natural processes, by F. Blouin. (2004)

No. 90 The southern headwaters at risk project: A multi-species conservation strategy for the headwaters of the Oldman River. Volume 2: Species Selection and Habitat Suitability Models, by F. Blouin, B.N.Taylor, and R.W.Quinlan (eds). (2004)

No. 91 Distribution, abundance and habitat selection of northern pygmy and barred owls along the eastern slopes of the Alberta Rocky Mountains, by M. D. Piorecky and D. R. C. Prescott. (2004)

No. 92 Survey of Aquatic Gastropods in the Central Parkland Subregion of Alberta, by D. R. C. Prescott, and M. M. Curteanu. (2004)

No. 93 The 2003 Loggerhead Shrike Survey in Alberta, by D. R. C. Prescott. (2004)

No. 94 Western (Aechmophorus occidentalis) and Eared (Podiceps nigricollis) Grebes of Central and Parkland Alberta: 2004 Field Summary, by G. Berg, L. Wilkinson, H. Wollis, and D. Prescott. (2004)

No. 95 Researching Amphibian Numbers in Alberta (RANA): 2004 provincial summary, by L. Wilkinson and G. Berg. (2004)

No. 96 Gillett's checkerspot in the southern headwaters at risk (SHARP) project area, by N.G. Kondla. (2005)

No. 97 Southern headwaters at risk project (SHARP) amphibian and western painted turtle (Chrysemys picta) surveys, 2003-2004, by K.J. Pearson. (2005)

No. 98 MULTISAR: A Multi-Species Conservation Strategy For Species at Risk: Year 3 Report, by B. L. Downey, B. A. Downey, R.W. Quinlan, and P. F. Jones. (2005)

No. 99 Implementation of the Alberta Piping Plover Recovery Plan, 2002-2004: Final Program Report, Alberta Piping Plover Recovery Team. (2005)

No. 100 Alberta Species at Risk Program and Projects 2003-2004, by Alberta Sustainable Resource Development, Fish and Wildlife Division. (2005) 
No. 101. The 2005 ferruginous hawk inventory and population analysis, by B. L. Downey. (2005)

No. 102 Western Spiderwort (Tradescantia occidentalis) Inventory in Alberta, 2005, by B.L. Remarchuk. (2006)

No. 103 Reproductive Biology of Female Prairie Rattlesnakes (Crotalus viridis viridis) in Alberta, by D. Jørgensen and J. Nicholson. (2007)

No. 104 Magrath Northern Leopard Frog Reintroduction Program: Final Report, by K. Romanchuk and R. Quinlan. (2005)

No. 105 The Southern Headwaters at Risk Project: A Multi-Species Conservation Strategy for the Headwaters of the Oldman River, Volume 3, Landscape Management - Selection and Recommendations, by F. Blouin. (2006)

No. 106 The Southern Headwaters at Risk Project: A Multi-Species Conservation Strategy for the Headwaters of the Oldman River Volume 4, BMP's and Land Use Guidelines for Focal Species, by F. Blouin. (2006)

No. 107 The Southern Headwaters at Risk Project: A Multi-Species Conservation Strategy for the Headwaters of the Oldman River, Volume 5, Landscape Pressures on Wide-ranging Species, by F. Blouin. (2006)

No. 108 MULTISAR: A Multi-Species Conservation Strategy for Species at Risk 2005-2006 Report, by B. A. Downey, B. L. Downey, R. W. Quinlan, and P.F. Jones. (2006)

No. 109 Western Rattlers and People: Conserving rattlesnakes in Lethbridge, by R.D. Ernst and R.W. Quinlan. (2006)

No. 110 Researching Amphibian Numbers in Alberta (RANA): 2005 Provincial Summary, by L. Wilkinson and G. Berg. (2006)

No. 111 Inventory of the Pinhorn Soapweed (Yucca glauca) and Yucca moth (Tegiticula yuccasella) population, 2004, by K. Foreman, J. Chandler, and L. Matthias. (2006) 




LIBRARY AND ARCHIVES CANADA

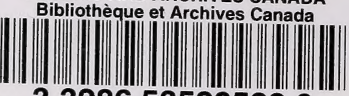

33286535295220 